Bogumił Chmiel

Nowy Sącz

\title{
Uwagi na temat możliwości rozróżniania między „formą” a „sensem” ekspresji religijnej
}

Celem niniejszego artykułu jest analiza założenia stanowiącego fundament procesu, który na potrzeby niniejszego artykułu określić można jako intencjonalnie zmienianie „form religijnych”. Zaproponowane określenie nie jest być może najlepsze i zapewne można znaleźć wyrażenie lepiej oddające scharakteryzowaną poniżej rzeczywistość; wskazuje ono jednak na zasadnicze presupozycje stojące za współczesną teologią i duszpasterstwem, przez co już na wstępie pozwala uchwycić istotne aspekty omawianego zagadnienia. Mowa mianowicie o rozróżnieniu pomiędzy „formą” ekspresji religijnej a jej „sensem" ${ }^{\prime}$. Zanim terminy te zostaną scharakteryzowane, a stojące za nimi założenie wyeksplikowane i poddane krytyce, należy podkreślić, że rozważana kwestia nie dotyczy zmian w „formach” religijnych w ogóle, ale wyłącznie w tych, które są przeprowadzane w sposób zamierzony. Oczywiście nie każdy, kto deklaruje poparcie dla takich przekształceń bądź w sobie właściwy sposób je realizuje, musi być w pełni świadomy ich charakteru. Rzecz jednak w tym, że współczesne zmiany w szeroko pojętym głoszeniu doktryn religijnych są efektem stopniowego urzeczywistniania zamysłu wynikającego w pierwszym rzędzie z określonego pojmowania natury religii. Scharakteryzowanie

\footnotetext{
1 Zarówno w tytule, jak i w całym artykule pojawia się zwrot „ekspresja religijna” oznaczający wszelkie środki wyrażania treści religijnych. Został on użyty rozmyślnie, aby uniknąć sugestii ograniczenia przedmiotu analiz do „wyrażeń” religijnych, tj. terminów i zdań składających się na traktaty teologiczne, formuły liturgiczne, wyznania wiary. Język religii (symbole, gesty, architektura, artefakty) jest bowiem o wiele bogatszy i nie daje się zamknąć w kategoriach języka naturalnego.
} 
istoty tej perspektywy stanowi pierwszą część artykułu, w drugiej przedstawiono fundamentalne założenie właściwe takiej wizji, a w trzeciej poddano je krytycznej analizie. Należy wreszcie zaznaczyć, że chociaż przedstawione rozważania dotyczą w pierwszym rzędzie chrześcijaństwa, to mogą być odniesione także do innych wyznań i religii.

Podejmując się charakterystyki zjawiska określonego mianem zmian „form religijnych”, warto powołać się na na nieco przydługi cytat, który doskonale przybliża istotę tego procesu. W zakończeniu swoich rozważań na temat eschatologii pierwszych wieków chrześcijaństwa Henryk Pietras stwierdza:

Pierwszą rzeczą jest to, w co ktoś wierzy lub myśli; drugą jest to, co sobie na ten temat wyobraża, trzecią dopiero są słowa, z pomocą których się wypowiada. Analogiczne stopniowanie możemy zaobserwować u tego, kto słucha: ktoś słyszy słowa, na ich podstawie wyobraża sobie rzeczy, o których słyszy, a następnie dochodzi do wiary, czy też sformułowania własnych poglądów. Język i wyobraźnia są uwarunkowane kulturą, tradycją rodową lub narodową, lekturami całego życia, doświadczeniami, a wręcz fauną i florą danego miejsca. Przekazywanie wiary poddane jest tym samym regułom i koniecznie trzeba sobie zdawać $z$ tego sprawę. Mamy aż nadto przykładów katechezy, która każe wierzyć w starożytne mity, tak jakby były one treścią wiary. Według wielu katechetów i kaznodziejów, żeby być dobrym chrześcijaninem, trzeba wierzyć w Szeol, w trąby anielskie, w ogród rajski Adama i Ewy i tak dalej. Innymi słowy mówiąc, zatrzymują się oni na wyobrażeniach związanych z kulturą starożytnych, a nie na objawieniu. Spotykamy również gorliwców, odzianych w jakiś autorytet, którzy uważają za wielce niebezpieczne takie mówienie, które chciałoby się oderwać od tych wyobrażeń i nie zwracają uwagi na to, że są one bardzo odległe od współczesnej mentalności ${ }^{2}$.

Poniższe rozważania w wielu miejscach odwołują się do przytoczonych słów, należy zatem podkreślić, że praca, z której pochodzą, nie dotyczy zagadnień, o których mowa w cytacie; są one raczej wtrąceniem, a tym samym krytyka skierowana w ich stronę nie odnosi się do całości pracy ani nawet głównego jej tematu. Wybrany cytat jest jedynie przykładem uniwersalnej tendencji do „modernizacji” języka teologii i duszpasterstwa, której istotnym elementem jest porzucenie archaicznych sposobów wyrażania wiary (jako nieprzystających do współczesnej mentalności) i poszukiwanie nowych „form”

2 H. Pietras, Eschatologia Kościoła pierwszych czterech wieków, Kraków, s. 134-135. 
dla przekazu boskich prawd. Tendencji ta jest na tyle powszechna, oczywista i traktowana na zasadzie truizmu, że niemal niezauważalna dla większość wiernych, teologów i duszpasterzy. Zasadniczym celem artykułu jest wykazanie, że takie zastępowanie starych „form” nowymi jest niewykonalne, opiera się bowiem na błędnym przekonaniu o możliwości rozróżnienia między względną (ludzką) „formą” ekspresji religijnej a jej absolutnym (boskim) „sensem”.

Cała przytoczona powyżej wypowiedź zakłada fundamentalne rozróżnienie między treścią (materią, sensem, istotą) wypowiedzi a jej formą (postacią, „wyobrażeniem”), w której owa treść jest wyrażona. Ów sens jest „tym, w co ktoś wierzy lub myśli”, do formy zaś zalicza się „to, co sobie na ten temat wyobraża, [...] słowa, z pomocą których się wypowiada”. Sens jest czymś niezmiennym i obiektywnym - istotą przekonania/wiary, podczas gdy zmienna forma podlega licznym uwarunkowaniom społecznym i kulturowym. Cała krytyka, jaką autor przywołanego cytatu kieruje pod adresem katechezy, kaznodziejów i wątpliwych autorytetów, sprowadza się do zarzutu, wedle którego, ignorując to (przyjmowane na zasadzie oczywistości) rozróżnienie, czynią oni przedmiotem wiary archaiczne „formy”, które - jako „odległe” od współczesnej mentalności - utrudniają przekazanie obiektywnego i ahistorycznego sensu Ewangelii.

Warto podkreślić, że przywołane założenie służy nie tylko krytyce „zachowawczych" (tj. nadmiernie przywiązanych do starych „form”) trendów w teologii i duszpasterstwie, ale stanowi również podstawę do wszelkich form „uwspółcześniania” nauczania Kościoła. Zwolennicy modernizacji języka teologii, liturgii i duszpasterstwa są zgodni, że ich propozycje nie dotyczą „sensu” Ewangelii, a jedynie „formy”, w jakiej jest przekazywana, czyli tego, co już ze swojej natury jest zmienne i relatywne ${ }^{3}$. Cały wysiłek teologiczny i duszpasterski zmierza rzekomo w kierunku znalezienia takich „form”, które - odpowiadając współczesnej mentalności - będą bardziej „przeźroczyste” dla człowieka xx i xxı wieku, a jednocześnie oddadzą „sens” Ewangelii. Ta „przeźroczystość” polegać ma zasadniczo na tym, że w przypadku starych „form” przekazu (narracji o rajskim ogrodzie, Szeolu, postaciach anielskich) są one dla współczesnego człowieka na tyle niezrozumiałe, że zamiast płynnie (niejako automatycznie) odsyłać do wyrażanej w nich zbawczej prawdy (tj. owego „sensu”), same stały się przedmiotem namysłu i krytyki. Umysł zatrzymuje się w ten sposób na problematycznej formie, zamiast poprzez nią ujmować obiektywną treść. Nowe formy, bardziej odpowiadające współczesnej mentalności, winny zmienić tę sytuację - teolog żyjący we współczesnej kulturze i obeznany

3 Por. R. P. Coomaraswamy, The destruction of Christian tradition, Bloomington 2006, s. 83-84. 
z właściwym jej „językiem”, wybiera odpowiednie kategorie, w które „ubiera” orędzie Jezusa Chrystusa bez utraty integralności „sensu”4.

Jeśli czytelnik uważa powyższe uwagi za oczywiste i nieproblematyczne, to jest to najlepszy dowód na powszechność takiej perspektywy oraz jej głębokie zakorzenienie w umysłach teologów i wiernych. Dodać należy, że poszukiwania nowych form nie zawsze polega na entuzjastycznym korzystaniu z kanonów współczesnej kultury. Często ma ono zgoła odmienny kierunek i zmierza ku wydobyciu tak zwanego „pierwotnego” chrześcijaństwa - jego najczystszej postaci (doktryna, kult, organizacja wspólnot), właściwej pierwszym wspólnotom. Takie podejście zakłada, że pierwotny, „,czysty” sens orędzia Chrystusa został na przestrzeni dziejów zaciemniony i zagubiony głównie za sprawą nieadekwatnych form, w jakich był wyrażany (idee greckiej filozofii, rzymskie prawo, naleciałości pogańskie) i które wykrzywiły autentyczny sens Objawienia ${ }^{5}$. Obecnie, po wiekach błędów i wypaczeń, należy ów sens ponownie odkryć i przedstawić światu w „czystej” postaci. Nie trzeba dodawać, że owo „teraz”, o którym mówią zwolennicy takiego podejścia, trwa już przynajmniej od czasów renesansu (devotio moderna) i trudno rozstrzygnąć, czy wreszcie nastało ${ }^{6}$. Mając na uwadze zarysowane tendencje, można dostrzec, w jak szerokim spektrum myśli obracają się współczesne wysiłki modernizacji „języka” Ewangelii. Mimo iż przybierają one wielorakie postacie - od machania flagami na mszy św. i wieszania hostii na żyłce po zmiany liturgiczne i wysublimowane teologie - to bazują na wskazanym rozróżnieniu między formą i sensem, traktują je jako oczywiste, a tym samym pozbawione konieczności dowodu.

4 W ten sposób, jako „nowy, nieznany przedtem sposób podania” ogromnego bogactwa treści, określa sobór watykański II List apostolski Tertio Milenio Adveniente. Por. tamże, s. 20.

5 Por. E. Gilson, Jedność doświadczenia filozoficznego, przeł. Z. Wrzeszcz, Warszawa 1968, s. 77-8o. Gilson podaje tylko wybrane przykłady wpływowych myślicieli. W rzeczywistości przywołana perspektywa stała u źródeł całego ruchu reformacyjnego. Esencją takiego myślenia była zasada sola scriptura gwarantująca rzekomo źródłowy charakter teologii reformacyjnej.

6 Warto pamiętać, że przekonanie o zasadniczej różnicy między zmienną i ludzką formą a niezmiennym, boskim sensem podzielali nie tylko renesansowi krytycy scholastyki działający w imię pierwotnej czystości Ewangelii, ale także zwolennicy rozkwitającej w owych czasach filozofii wieczystej (philosophia perennis). Liczni entuzjaści tego nurtu (Mikołaj z Kuzy, Marcelo Ficino, Pico della Mirandolla, Aggostino Steuco) byli przekonani, że wszystkie główne tradycje religijne i filozoficzne są mniej lub bardziej adekwatnymi nośnikami („formami”) jednego pierwotnego Objawienia. Trudno w tym miejscu podejmować kwestię źródła powszechności w Xvi wieku tego mniemania, można jednak - na zasadzie hipotezy - przyjąć, że wynikała ona z ówczesnego rozwoju studiów lingwistycznych i towarzyszącej im hermeneutycznej perspektywy. 
Wątpliwości w stosunku do przywołanego rozróżnienia może nasunąć dyskusja, jaka toczy się przy okazji propozycji zmian w kwestiach dogmatycznych, liturgicznych czy teologiczno-moralnych. Bardzo często argumentem ich zwolenników jest wskazanie, że zmiany te dotyczą właśnie „formy”, nie zaś „treści” nauczania Chrystusa i Kościoła. Przeciwnicy z kolei głoszą coś wręcz przeciwnego - w ich mniemaniu zmianie ulega „treść, nie zaś tylko „forma”. Co więcej, ani jedna, ani druga strona nie kwapi się do wskazania kryterium, które można by uznać za niekwestionowaną podstawę dla takich rozróżnień. Zamiast tego powołuje się na poszczególne wypowiedzi (nieraz z różnych epok) mające rzekomo potwierdzać zajmowane stanowisko. Próba poszukiwania takiego kryterium może przybrać dwie formy. W pierwszej dysponujemy już „czystymi” treściami, co do których jesteśmy zgodni, że należą one do istoty nauczania Chrystusa. Następnie, poszukując wspólnych cech tych treści, możemy skonstruować kryterium, na bazie którego jesteśmy w stanie odróżnić kolejne „czyste” sensy należące do korpusu zbawczych prawd. Jednocześnie, na tej samej zasadzie, jesteśmy w stanie wskazać różną od nich, względną „formę”, którą można i należy dostosowywać do zmiennych warunków społecznych i kulturowych. Jak wspomniano powyżej, posiadanie treści, które na sposób „oczywisty” należą do istoty chrześcijaństwa, jest bardzo wątpliwe. Nawet gdyby takie wskazać (miłość Boga, Królestwo Boże, boskość Jezusa Chrystusa), to zaraz okazuje się, że ich zrozumienie wymaga interpretacji, a to już wikła nas w spory, w których problem rozróżnienia między sensem a formą odgrywa zasadniczą rolę ${ }^{7}$.

Z drugiej strony, można zacząć od wskazania kryteriów podziału na „sens” $\mathrm{i}$ „formę”, aby następnie na ich podstawie wyróżniać sensy należące do istoty chrześcijaństwa. W tym jednak przypadku problematyczne stają się postulowane kryteria, a dokładniej ich zasadność. Tutaj również pojawi się kwestia formy - zawsze można powiedzieć, że wskazane kryterium absolutyzuje daną postać (formę) nauczania pomijając jego istotę.

Mamy zatem dwie możliwości:

1. Zaczynamy od niekwestionowanej („czystej”) treści wydobytej z form, w których się pojawiły w danym momencie dziejowym, a następnie dobieramy do nich odpowiednie formy „pasujące” do naszych czasów.

7 Odwołanie się do Tradycji czy Nauczycielskiego Urzędu Kościoła nie jest tutaj wyjściem, bowiem zarówno w jednym, jak i drugim przypadku stosuje się rozróżnienie na „sens” wypowiedzi i jej „formę”. 
2. Przyjmujemy jako niepodważalne pewne kryteria, na podstawie których wskazujemy różnicę między absolutną treścią i relatywną formą, aby następnie przeprowadzić modernizację formy przy zachowaniu treści. W obu sytuacjach musimy zacząć od jakiegoś niekwestionowanego fundamentu, aby na jego podstawie odróżnić absolutny i niezmienny sens od względnej i historycznie uwarunkowanej formy ${ }^{8}$.

Zarówno w jednym, jak i w drugim przypadku efekt takiego zabiegu może zostać zakwestionowany poprzez odwołanie do argumentu (zakładającego omawiane rozróżnienie) wskazującego, że dane kryterium lub treść nie odwołuje się do „czystego” sensu, a wyłącznie względnej „formy”. Taki wybieg jest za każdym razem możliwy i prawomocny - nie da się bowiem wykazać, że w danym wypadku już na pewno dotarliśmy do czystego „sensu” bądź absolutnego kryterium. Zawsze można dowodzić, że sens danej ekspresji leży „głębiej” lub „gdzie indziej”. Te topograficzne określenia sugerują, że próby ustalenia kryterium odróżnienia sensu od formy lub wskazania „czystych” treści przypominają przygotowania podróży do miejsca, którego położenia nikt nie zna, nikt nie wie, jak ono wygląda i w którym nikt nigdy nie był (tym miejscem jest ów „czysty” sens) - rysuje się mapy, ocenia koszta, dyskutuje nad wartością podróży, podczas gdy nie wiadomo nawet, czy to miejsce w ogóle istnieje. Jedyne, co wiemy, to - że jesteśmy w podróży i znamy dotychczas przebytą drogę.

Powyższe trudności mogą prowadzić do wniosku, że samo rozróżnienie na sens i formę jest błędne - każdy sens jest nam dany poprzez i z właściwą mu formą, która decyduje o jego postaci, tj. o tym, że dane $x$ jest rozpoznane jako sensowne. Każda „forma” zaś jest formą tylko o tyle, o ile sama w sobie

8 Przedstawione rozróżnienie nawiązuje do propozycji R. S. Chisholma odnoszącego się do uzasadnienia epistemicznego w ogóle. Wydaje się jednak, że skoro analizowana kwestia ma charakter poznawczy to przytoczone rozróżnienie jest jak najbardziej na miejscu. Por. R. S. Chisholm, Teoria poznania, przeł. R. Ziemińska, Lublin 1994, s. 19-21.

9 Można przytoczyć jeszcze jedno, bardziej chyba adekwatne porównanie. Przed analogicznym problemem stanęli zwolennicy badania świadomości jako punktu wyjścia filozofii - jak mianowicie sprawdzić, czy nasze przedstawienia adekwatnie odzwierciedlają świat poza umysłem. Aby móc tego dokonać, trzeba by stanąć „poza” relacją przedstawienia-świat, podczas gdy wszelkie nasze poznanie zmysłowe dokonuje się poprzez przedstawienia. Podobnie w analizowanym przypadku, aby zbadać relację sensu i formy, trzeba by przyjąć taką perspektywę, w której ujmujemy czyste sensy lub czyste formy, lub (co byłoby najlepsze) obie wielkości jednocześnie. Tymczasem wszelkie nasze myślenie sensów dokonuje się za pomocą form. 
jest związana $\mathrm{z}$ jakimś sensem ${ }^{10}$. Nie istnieje sens pozbawiony formy ani coś, co można by określić jako formę, która - jako „pusta” - byłaby całkowicie pozbawioną sensu. Każda forma jest inherentnie nacechowana sensem (lub nie jest identyfikowana jako forma), wszelki sens zaś jest pojmowany jako taki tylko poprzez właściwą mu formę (w przeciwnym wypadku nie jest rozpoznawany jako sensowny). Nic nie wskazuje na istnienie „czystego” sensu, bytującego niczym platońska idea w jakiejś obiektywnej, logicznej sferze czy nawet - na wzór arystotelesowskiej formy - w naszych umysłach. Nie można tym samym wskazać, na sposób absolutny, mniej lub bardziej „odpowiednich” form dla danego (ujmowanego jako „czysty”) sensu, podobnie jak nie istnieje „pusta” forma, którą można „dopasować” do sensu uprzednio rozpoznanego.

Aby dokładnie wyjaśnić tę tezę, warto wrócić do przywołanego cytatu oraz teorii, która explicite wyraża stojące za nim idee. W przytoczonym cytacie czytamy: „Pierwszą rzeczą jest to, w co ktoś wierzy lub myśli; drugą jest to, co sobie na ten temat wyobraża, trzecią dopiero są słowa, z pomocą których się wypowiada”. Mamy zatem najpierw pewien sens, następnie nasze wyobrażenia na jego temat i na końcu formy językowe, za pomocą których ów sens jest komunikowany. W taki sam sposób relację między przedmiotami mentalnymi a językowymi przedstawia Mieczysław A. Krąpiec: ,język zawsze jest znakiem myśli, ale nie samą myślą. Będąc tworzywem, materiałem, służącym do coraz precyzyjniejszego sformułowania ludzkiej myśli, pełni w stosunku do niej funkcję czynnika [...] materialnego, jak kamień w stosunku do rzeźby, a płótno w stosunku do koloru obrazu"' ${ }^{\text {.11 }}$ Myśl jest zatem czymś różnym od języka i jego kategorii, poprzez które możemy wyrażać nasze myśli w mniej lub bardziej adekwatny sposób ${ }^{12}$. Powstaje jednak pytanie, na jakiej zasadzie możemy wiedzieć, że dana forma (obojętnie, czy językowa, czy wyobrażeniowa) dobrze „pasuje” do naszej myśli. Co porównujemy między „pustą" formą a „bezforemną" myślą (sensem), aby wskazać, że lepiej lub gorzej „pasują” do siebie? Wszak jeśli myśl „pasuje” do formy, to właśnie na mocy swojej własnej formy, która odpowiada tej drugiej, decydującej z kolei o właściwym

10 Widać wyraźnie, jak zwodniczy jest tutaj język. Sama wypowiedź sugeruje nam, że istnieje logiczna (i domyślnie - ontologiczna i epistemologiczna) różnica między sensem a jego formą, która „decyduje o jego postaci”, o tym, że x „ma” taki a taki (czyli różny od samego x) „sens”. Wynika to $\mathrm{z}$ faktu, że rozróżnienie na formę i sens jest zasadne w określonym paradygmacie językowym. Błąd pojawia się wtedy, gdy próbuje się ową relację zuniwersalizować.

${ }_{11}$ M. A. Krąpiec, Język i świat realny, Lublin 1985, s. 48.

${ }_{12}$ Por. tamże, s. 47. 
jej sensie (polegającym choćby i nawet wyłącznie na byciu odpowiednim dla wyrażenia danej myśli). Mówiąc obrazowo, między „bezforemnym” sensem a „pustą" formą nie ma nic, co mogłoby sprawić, że wzajemnie sobie „odpowiadają”, „pasują” do siebie. Wreszcie, ujmując rzecz z perspektywy fenomenalnej, czy aby na pewno mamy jakiekolwiek „czyste” sensy, które następnie „ubieramy” w językowe formy, czy może raczej, w toku refleksji, okazuje się, że - niczym wędrowiec wyłaniający się z mgły - nasza myśl już ma daną formę, którą dzięki namysłowi rozpoznajemy?

Wydaje się, że w obliczu przytoczonych trudności trzeba przyznać, iż formę można porównać jedynie $\mathrm{z}$ inną formą, a nie jakimś „bezforemnym” sensem czy myślą. Podobnie dobieranie „lepszych” form dla danego uprzednio sensu opiera się na rozpoznaniu owego sensu przez pryzmat przypisanej mu już uprzednio formy, a następnie wskazaniu jej jako tej, która ma go „lepiej” wyrażać (np. ze względu na kontekst wypowiedzi). Nie mamy i nie możemy mieć dostępu do żadnych „czystych” sensów wyrażeń, mamy tylko konkretne wypowiedzi denotujące określone stany rzeczy. Taka sytuacja zachodzi nie tylko w przypadku języka naturalnego, ale także symbolicznego, któremu trzeba będzie poświęcić więcej uwagi.

Powyższe analizy można uzasadnić jeszcze w inny sposób, niestety nieco komplikując sam wywód. Ksiądz prof. Pietras słusznie zauważa, że: „Język i wyobraźnia są uwarunkowane kulturą, tradycją rodową lub narodową, lekturami całego życia, doświadczeniami, a wręcz fauną i florą danego miejsca. Przekazywanie wiary poddane jest tym samym regułom i koniecznie trzeba sobie zdawać z tego sprawę". Innymi słowy, sposób, w jaki odbiorcy rozumieli Objawienie, zależy od szeregu czynników, które to rozumienie kształtowały zwolennik tezy o różnicy między formą a sensem powiedziałby: nadawały mu „formę". Wezwanie, abyśmy o tym pamiętali i (w domyśle) umieli odróżniać te relatywne formy od absolutnej treści, sugeruje, że my (tj. ci, którzy dostrzegli prawdziwy sens Ewangelii i odróżnili go od przemijających form przekazu) już nie jesteśmy poddani tym uwarunkowaniom. Tymczasem jest to absurd. Nasze rozumienie dziejów, w tym minionych „form” religijnych, jest tak samo uwarunkowane zmiennymi czynnikami naszej kultury, jak rozumienie Objawienia w czasach patriarchów czy apostołów było uwarunkowane kulturą ówczesną. Co więcej, najlepszym dowodem takiego uwarunkowania są same dzieje teologii. Doszukiwanie się w Objawieniu i Tradycji idei egalitaryzmu społecznego, demokracji, równouprawnienia kobiet, dystrybucjonizmu, ekologii, rozdziału Kościoła od państwa i innych zupełnie nowożytnych idei pokazuje, że każda epoka (a nawet poszczególne grupy wiernych) „widzi” 
w dziejach to, co ukształtowały jej własne uwarunkowania kulturowe „tworzące” ujmowane sensy. Leżąca u podstaw takich propozycji oświeceniowa teza o wyjątkowej sytuacji poznawczej człowieka Xxi wieku wyzwolonego z mocy "przesądów” nie ma żadnego uzasadnienia - nie ma żadnych podstaw, aby sądzić, że współczesne myślenie jest mniej uwarunkowane niż myślenie ludzi z epoki Abrahama czy Mojżesza. Rzecz jedynie w tym, że zapewne są to inne uwarunkowania, nie zaś że ich zupełnie brak ${ }^{13}$.

Czy zatem rozróżnienie na formę i treść wypowiedzi jest zupełnie nieadekwatne i każda zmiana formy jest tożsama ze zmianą sensu? Można bronić stanowiska, wedle którego rezygnacja z koncepcji obiektywnego „sensu” absolutnie różnego od relatywnych historycznie „form”, w których ów „sens” się przejawia, nie jest tożsama $\mathrm{z}$ odrzuceniem bardziej umiarkowanego poglądu, w którym te dwie wielkości funkcjonują już nie na zasadach absolutnego podziału, ale jako kategorie zrelatywizowane do określonego kontekstu - paradygmatu. Intuicji rozwiązania, które poniżej przedstawiono, można doszukiwać się w poglądach Willarda van Ormana Quine’a, a ich zasadniczy zrąb nawiązuje do myśli Thomasa Kuhna i Paula Feyerabenda. Zdaniem Quine’a można mówić o takim samym znaczeniu terminów (form) na gruncie istniejących już struktur językowych, które zachodzenie relacji synonimiczności zakładają i określają na zasadzie postulatów ${ }^{14}$. Oczywiście takie postulaty są niczym więcej jak poręcznymi „umowami”, które - w razie potrzeby - można

${ }^{13}$ Powyższe uwagi można rozwinąć w następujący sposób. Wszystko, co warunkuje/kształtuje nasze rozumienie danego sensu, jest jednocześnie tym, co umożliwia jego uchwycenie. Gdyby nie było owych uwarunkowań, o których wspomina przywołany autor, to jak ówcześni ludzie mogliby zrozumieć boskie orędzie? Musieliby mieć inne kategorie wynikające z innych uwarunkowań, umożliwiające zrozumienie Objawienia. Trudno jednak wyobrazić sobie, aby mogli cokolwiek pojąć (a już na pewno przekazać kolejnym pokoleniom) w sposób absolutnie niezależny od kategorii kształtujących ich kulturę. Podobnie jest z nami, nasze rozumienie świata (w trym przeszłości i jej wytworów) również dokonuje się przez pryzmat naszej kultury. Uwagi ks. Pietrasa są tego najlepszym przykładem, odzwierciedlają bowiem oświeceniową wiarę w możliwość „oczyszczenia” ludzkiego umysłu $\mathrm{z}$ irracjonalnych naleciałości.

14 Por. W. V. Quine, Z punktu widzenia logiki, przeł. B. Stanosz, Warszawa 2004, s. 63-64. Oczywiście tak charakteryzowane pojęcie „synonimiczności” w żadnym przypadku nie spełnia wymagań, jakie Quine stawia temu terminowi w swoich analizach. Chodzi tutaj raczej o swoistą definicję kontekstową - używanie danego wyrażenia w kontekstach, które możemy określić jako paradygmatyczne, wyznacza to, co Quine określa jako „reguły semantyczne” funkcjonujące na zasadzie kompetencji językowej danej wspólnoty. Należy mieć na uwadze, że użyte tutaj terminy „wyrażenie”, „język” rozumiem bardzo szeroko, jako wszelkie formy ekspresji (także symbolicznej), której w danej społeczności przypisuje się znaczenie. 
zmieniać. Owe zmiany nie zachodzą jednak chaotycznie - na ogół zachowane zostaje to, co Feyerabend nazywa „ciągłością znaczenia” - w kolejnych wypowiedziach poszczególne ich elementy mają takie samo znaczenie, nawet jeśli (to już mój dodatek) ich forma ulega zmianie ${ }^{15}$. Wystarczy tylko, aby reguły semantyczne funkcjonujące w danej wspólnocie na bieżąco wyznaczały relacje synonimiczności. Każdy kompetentny użytkownik danego języka potrafi wychwycić jednakowe „sensy” i odróżnić je od zmiennych „form”; nabycie takiej umiejętności jest elementem kształcenia kolejnych pokoleń użytkowników języka. Rzecz w tym, że gdy zachodzą „rewolucje” kulturowe, zmienia się między innymi słownictwo - formalnie język może pozostać taki sam, ale poszczególne terminy denotują już inne rzeczywistości, co przekłada się z kolei na relacje syntaktyczne. Taka zmiana nie jest jednak wyłącznie odejściem od danego języka jako pewnego (zewnętrznego wobec podmiotu) narzędzia, ale „zmianą świata” - opisywaną przez Thomasa Kuhna w jego książce Struktura rewolucji naukowych, rewolucją w rozumieniu rzeczywistości, w której zasadniczą rolę odgrywa język, a wraz z nim relacje synonimiczności, stanowiące integralny element każdego paradygmatu ${ }^{16}$.

Aplikacja powyższych uwag do kwestii religii wygląda następująco. Jednym z fundamentalnych „elementów” tworzących religijne postrzeganie świata kształtujących swoisty „horyzont” i „tło”, w którym ujawniają się poszczególne sensy - jest język (kod) danej kultury. Pojęcia „języka” nie należy jednak rozumieć tak wąsko, jak pojmował je Quine, ale możliwie najszerzej - jako wszelkie zrozumiałe (w danym czasie i dla określonej społeczności) postacie ekspresji. Jednym z elementów takiego języka są „reguły synonimiczności” pozwalające

${ }_{15}$ Por. P. K. Feyerabend, Jak być dobrym empirysta, przeł. K. Zamiara, Warszawa 1979, s. 29-30.

${ }_{16}$ W kwestii rozumienia paradygmatu por. T. Kuhn, Struktura rewolucji naukowych, przeł. H. Ostromęcka, Warszawa 2009, s. 31-33. W moim przekonaniu wyrażenia składające się na „zespół uznanych teorii” funkcjonują nie tylko jako neutralne nośniki („formy”) uznanej za obowiązujące „treści” (jak zdaje się postulować Kuhn), ale także jako wyrażenia, które w sposób normatywny postulują sposób używania pojawiających się w nich pojęć (w tym zasad ich „synonimiczności” por. P. K. Feyerabend, Jak być dobrym empirystą, dz. cyt., s. 48-50). Przykładowo, stopniowe przyjęcie arystotelesowskiej wizji świata wyrażonej przez pojęcia: kosmosu, natury, substancji, aktu i możności, wkomponowanych w cały schemat myśli Stagiryty, stanowiło normatywną eksplikację rzeczywistości, w kontekście której zrozumiano sens Ewangelii. Owo „zrozumienie” nie funkcjonowało na zasadzie świadomego użycia danych pojęć dla uprzednio już uznanych sensów (przypominającego założenie okularów celem dostrzeżenia niewidocznych gołym okiem elementów), ale raczej jako wytworzenie sensu na bazie względnie apriorycznych (tj. przyswojonych poprzez wychowanie i edukację) kategorii. 
w miarę bezbłędnie odróżniać treść od formy i zmieniać te drugie, przy zachowaniu pierwszych. Oczywiście cała struktura tak szeroko pojętego języka i jego reguł nie jest czymś zewnętrznym względem poszczególnych podmiotów i ich „prywatnych sensów”, ale immanentnym tłem konstytuującym „świat" wspólnoty - uznawany za oczywisty sposób, w jaki rozumieją rzeczywistość (siebie samego, wszechświat, Boga, role i normy społeczne, przyrodę, historię). Przykładowo, w religiach, w których język „mityczny” stanowi medium rozumienia rzeczywistości, idea osi łączącej niebo z ziemią może być wyrażona w postaci (formie) drzewa, góry, wieży, słupa, drabiny, krzyża, a nawet świecy trzymanej przez umierającego. Wszystkie te „formy” odnoszą do tego samego „sensu” (a tym samym rozróżnienie na te dwie wielkości jest zasadne) tylko dlatego, że funkcjonują w szerszym kontekście symbolicznym, który jako całość wyznacza relacje „synonimiczności” poszczególnych symboli. Innymi słowy, konkretny przedmiot $x$ ma znaczenie (teologiczne) $R$, takie samo, jak przedmiot $y$, tylko dlatego, że oba te przedmioty funkcjonują we wspólnej im strukturze kulturowej regulującej zasady ich używania lub w różnych strukturach, które jednak „przystają” do siebie, co pozwala znaleźć swoisty metajęzyk ujmujący relacje synonimiczności właściwych im „form” ekspresji. Trudno tutaj oczywiście mówić o wymienialności salva veritate poszczególnych elementów, ale idea symbolicznej „symetrii” kultur mitologicznych jest jak najbardziej na miejscu. Pytanie, jak to się dzieje, że poszczególne kultury są symetryczne, przekracza już ramy niniejszej analizy, lecz w perspektywie teologicznej może prowadzić do idei preparatio evangelica.

Gdy paradygmat ulegnie zmianie, to znaczy zmienią się fundamentalne twierdzenia stanowiące „krystalizację” sposobu myślenia danej kultury oraz normatywny model ekspresji, to - nawet jeśli zwolennicy nowego paradygmatu twierdzą, że mówią „to samo” co ich poprzednicy - co rusz okazuje się, że natrafiamy na takie trudności, jak opisano powyżej - treść zlewa się z formą i nie wiadomo, co jest jeszcze zmienną postacią wypowiedzi, a co już absolutnym sensem. Towarzyszą temu spory egzegetyczne, w tle których dostrzec można różnice doktrynalne, a każde stanowisko rości sobie miano ortodoksyjnego jedni na mocy kontynuacji „formy”, inni ze względu na rzekome odkrycie autentycznej „treści”. Aby zilustrować taki „przeskok”, dość wspomnieć o oporach w asymilacji myśli greckiej przez chrześcijaństwo oraz (po ponad tysiącu lat) krytycznej ocenie teologii opartej na filozofii Platona i Arystotelesa ze strony rozczarowanych scholastyką myślicieli renesansu. W obu przypadkach można podać przykłady zarówno obrońców „Czystego” chrześcijaństwa mówiących o „zdradzie” prawdziwego sensu Ewangelii przez filozofujących teologów, jak 
i obrońców „tradycji” wobec groźnego nowinkarstwa, które pod pozorem powrotu do korzeni (istoty) chrześcijaństwa propaguje herezje ${ }^{17}$.

Powyższe dociekania mogą się jawić jako zbyt teoretyczne, wręcz erystyczne, jednak nie są niczym nowym na gruncie refleksji zarówno nad naukami humanistycznymi, jak i nad filozofią. Dość wspomnieć, że ich zasadniczy rdzeń, odwołujący się do analiz Quine’a, doprowadził do poważnej dyskusji nad zasadnością koncepcji „sensu/znaczenia” jako pośrednika między wyrażeniami językowymi a zbiorami przedmiotów, a metodologie Kuhna i Feyerabenda stały się podstawą krytyki pozytywistycznej wizji nauki. Co więcej, zarysowany schemat myśli pozwala dostrzec, że złudzenie czystych „sensów”/ „znaczeń" ma na gruncie teologii to samo źródło, co w przypadku języka naturalnego. W języku naturalnym prowadzi do niego intuicyjne przekonanie o synonimiczności wypowiedzi; wydaje nam się, że możemy powiedzieć to samo na różne sposoby - „to samo” to właśnie ów „czysty” sens, podczas gdy „sposoby” to zmienne „formy”. Podobnie w teologii - wierzy się, że Kościół naucza „tego samego" od początku swojej misji, a jednocześnie - w obliczu zachodzących zmian - dopatruje się ich w „formach”, a nie „sensie” nauki. Analogicznie ma się rzecz w przypadku uwarunkowań kulturowych mających rzekomy wpływ jedynie na formę - człowiekowi xxI wieku wydaje się, że jest wolny od tych „przesądów”, które kształtowały myślenie ludzi w starożytności i średniowieczu, i dopiero on potrafi poznać „prawdziwe” chrześcijaństwo. Te dwie tendencje prowadzą to tego, że w obliczu kryzysu religii, zamiast starać się zachować formy, w których boska Prawda znalazła swój wyraz, lekceważy się je w imię pozornego powrotu do ,istoty” wiary.

Na zakończenie warto wspomnieć o kwestii, która wskazuje na istotność zarysowanych procesów, a tym samym zasługuje na większą uwagę. Chodzi mianowicie o desakralizację będącą konsekwencją rozróżnienia na sens i formę, chociaż (paradoksalnie) owo rozróżnienie może uchodzić za remedium na krytykę religii. Nowożytna ofensywa przeciwko religii rozwinęla się między innymi w kierunku krytyki historycznej - wykazania, że poszczególne postacie, zdarzenia i zjawiska opisywane na kartach Biblii nie mogły mieć miejsca i nie były niczym innym jak tylko wytworem wyobraźni. Obrońcy natchnionego

${ }_{17}$ Warto zauważyć, i jest to kolejna cecha potwierdzająca zgodność opisywanych idei z myślą Kuhna, że takie narzekania intensyfikują się, gdy „stary” paradygmat jawi się jako niewydolny i coraz mocniej widać potrzebę nowego. W przypadku teologii nowożytnej taki proces zaczął się w XIV wieku, a w wiekach XV i XVI widać go już bardzo wyraźnie. Sobór trydencki można pojmować jako instytucjonalne opowiedzenie się za „starą” formą i związaną z nią treścią. 
charakteru Pisma starali się wykazać jego boską naturę, wskazując właśnie na ów natchniony „sens”, różny do historycznej formy. W ich przekonaniu nowożytna krytyka jest słuszna, ale sięga jedynie, zależnej od człowieka i zrelatywizowanej do okresu dziejowego, formy Objawienia. Natchniony, a zatem święty, jest jedynie sens i to on pozostaje niezmienny, forma należy do sfery profanum i jej jedynym zadaniem jest czasowo wcielać to, co ze swej istoty jest absolutne i święte ${ }^{18}$. W ten sposób apologeci mogli przyłączyć się do chóru krytyków i w aurze naukowości pouczać opornych o nieprzystawalności „mitów” do współczesnej mentalności. Co więcej, stanęło przed nimi nowe zadanie - wydobycia i oddzielenia wewnętrznego sacrum sensu od zewnętrznego profanum formy.

Jeśli jednak powyższe analizy są słuszne, a więc rozróżnienie na formę i sens jest zasadne jedynie w określonym paradygmacie teologicznym, nie zaś absolutnie, to powstaje problem, jak traktować „formę” - jako sakralną czy profańską? Wiele wskazuje na to, że należy zdecydowanie opowiedzieć się za pierwszą możliwością. Najbardziej elementarne teofanie sakralizują cały przedmiot, a nie tylko jakiś wewnętrzny „sens”, który kapłani czy inne kompetentne osoby „wyodrębniają” z całości. Rozmaite formy religijnego tabu - ograniczenia kontaktu, nakazy i zakazy określonych zachowań wobec przedmiotów i miejsc - są dobitnym świadectwem świętości całych rzeczy, a nie tylko ich „sensów”. W katolicyzmie takie myślenie jest stosunkowo mocno obecne - kult świętych, patronów, relikwii, pojmowanie mszy świętej jako realnej ofiary, a hostii jako prawdziwego ciała Chrystusa, „naturalistyczne” rozumienie dziewictwa Najświętszej Marii Panny, opór wobec demitologizacji Pisma Świętego - wszystkie to jednoznacznie wskazuje na głęboko zakorzenione przekonanie, że świętość jest realną własnością/mocą całej rzeczy czy osoby. Co więcej, mając na uwadze archaiczne pojmowanie świata jako manifestacji bóstwa, w którym - choć niektóre przedmioty są bardziej „nasycone" świętością - cała rzeczywistość jest w jakimś stopniu przeniknięta Bożą obecnością, trzeba uznać, że wszelkie manipulacje przy rzekomej profańskiej „formie” (zwłaszcza dokonywane z perspektywy epoki, która w swojej pysze rości sobie prawa do zajmowania całkowicie nieuwarunkowanej perspektywy rozumienia) okazują się dotyczyć sakralnej istoty przekazu. Można przypuszczać, że samo teoretyczne rozróżnienie na sfery sacrum i profanum jest

${ }_{18}$ Nie trzeba dodawać, że bardzo często ów „sens” okazuje się zbiorem moralnych banałów, dziwnym trafem zbieżnych $\mathrm{z}$ aktualnymi trendami w kulturze. 
jednym z wielu przejawów desakralizacji - zamykania świętości w określonych „przestrzeniach”, z których każda kolejna okazuje się zbyt rozległa i trzeba ją zastąpić skromniejszą.

Powyższą tezę można uzasadnić poprzez odwołanie historyczne. Gdy przyjrzymy się dziejom relacji myśli greckiej i młodego chrześcijaństwa, zauważymy przyswajanie nie czystych „sensów” pasujących do istniejących już dogmatów, ale fuzję, w wyniku której powstaje myśl scholastyczna i właściwy jej sposób rozumienia świata. Dobitnym świadectwem „sakralizacji formy” jest funkcjonujące wówczas przekonanie, wedle którego pierwotne objawienie zostało dane ludziom przez postacie świętych, którzy później przekazywali je kolejnym pokoleniom ${ }^{19}$. Pragnąc bronić wyłączności chrześcijaństwa, tłumaczono podobieństwa między Objawieniem i filozofią zapożyczeniem/kradzieżą przez filozofów zbawczych idei od Mojżesza ${ }^{20}$. Takie wyjaśnienie jawiło się jako konieczne (i naturalne) jedynie przy braku rozróżnienia między świętością treści a osoby, którą ją odkryła/przekazała. Przyznanie, że pewne prawdy pojawiły się w myśli pogańskiej niezależnie od Objawienia wiązało się w ówczesnej mentalności z uznaniem, że również pogaństwo ma swoich „świętych”; tego zaś chciano uniknąć. Już u św. Justyna wyraźnie widać, jak uznanie nauki filozofów za prawdziwą sakralizuje nie tylko konkretną postać, ale całą dziedzinę, w której się ona pojawiała ${ }^{21}$.

Przekonanie o świętości filozofów towarzyszące uznaniu, jakim cieszyła się ich myśl, przewijało się od starożytności, przez całe średniowiecze, aby wyjątkowo mocno zaznaczyć swoją obecność w epoce renesansu. Cześć dla „boskiego Platona” i mitycznych mędrców (pia philosophoi) przekazujących

19 Przykładowo św. Justyn pisze: „Dawnymi czasy, jeszcze przed owymi pseudofilozofami, żyli błogosławieni, sprawiedliwi i mili Bogu mężowie, którzy przemawiali z natchnienia Bożego i przepowiadali rzeczy przyszłe, jakie się teraz spełniają; zowią ich prorokami. Oni jedni prawdę poznali i ludziom ją oznajmili [...]. Pisma ich istnieją po dziś dzień, ku wielkiej korzyści czytelników, gdyż mówią o początku i końcu wszechrzeczy, oraz o wszystkim, co filozof wiedzieć powinien”. Justyn Męczennik, Apologia, [w:] M. Michalski, Antologia literatury patrystycznej, t. 1, Warszawa 1975, s. 102.

${ }^{20},[w]$ ielu bowiem filozofów greckich, staranniejszych od innych w swych badaniach, pościągało cudzołożnie (bezprawnie) swe nauki czy to z samego Mojżesza, czy jego naśladowców, przy czym jedne z twierdzeń Mojżeszowych podawali oni po prostu za własne oryginalne zapatrywania, inne zaś, których sensu dobrze nie rozumieli, przedstawiali w formie bajecznych opowiadań, przybranych w szatę uczonych komentarzy". Tacjan Syryjczyk, Przemowa do Greków, [w:] M. Michalski, Antologia literatury patrystycznej, dz. cyt., s. 116.

${ }^{21}$ Justyn Męczennik przyznający Sokratesowi wyjątkową rolę w dziejach zbawienia jednocześnie pojmuje jego postać w kategoriach świętego - jego cierpienia mają taki sam charakter i źródło jak cierpienia chrześcijan. Por. Justyn Męczennik, Apologia, dz. cyt., s. 92. 
od zarania dziejów prawdę objawioną wszystkim ludziom przez Boga zawsze łączyła w sobie przypisanie myśli platońskiej boskiego charakteru i sakralizację osób zaangażowanych w jej transmisję ${ }^{22}$. Można powiedzieć, że świętość treści niepostrzeżenie przenosi się na formę, a ich oddzielenie jest efektem krytycznej egzegezy czasów nowożytnych. Nawet współcześnie można zaobserwować to samo zjawisko - wykazanie boskiej legitymizacji danego zjawiska czy idei jednoznacznie wiąże się z przypisaniem specyficznego statusu ich „nośnikom”23.

\section{Podsumowanie}

Należy podkreślić, że powyższe rozważania w żaden sposób nie roszczą sobie pretensji do wyczerpującego potraktowania zagadnienia i prezentacji proponowanych stanowisk. Są raczej szkicem problemów, jakich nastręcza przyjęcie absolutnego rozróżnienie na materię/sens i formę przekazu. Wnioski, jakie nasuwają się na tym etapie analiz, można przedstawić następująco:

1. Bardzo problematyczne wydaje się rozróżnienie na absolutny „sens” i historycznie relatywną "formę” jako autonomiczne rzeczywistości powiązane w konkretnej postaci chrześcijańskiego nauczania. Ani analiza logiczna tych pojęć, ani fenomenologiczna refleksja nad sensami pojawiającym się w naszej świadomości, ani historyczny namysł nad dziejami doktryny nie pozwalają uzasadnić takiego rozróżnienia. Wręcz przeciwnie, wskazują one na jedność sensu i formy jako rzeczywistości, w której tylko pozornie daje się wyodrębnić postulowane elementy.

2. Jedyne uzasadnione rozróżnienie na sens i formę zdaje się funkcjonować w obrębie teologicznych paradygmatów, w których - na mocy immanentnych

${ }^{22}$ Opinię o boskim charakterze nie tylko filozofii platońskiej, ale i samego Platona można znaleźć w: M. Ficino Platonic theology, vol. 1, trad. M. J. B. Allen, J. Hankins, London 2001, s. 9. Ten sam myśliciel przetłumaczył i opatrzył wstępem Corpus Hermeticum - dzieło przypisywane Hermesowi Trismegistosowi. We Wstępie naszkicował schemat dziejowego przekazu prawdy od Mojżesza, przez Hermesa Trismegistosa, Orfeusza, Protagorasa, do Platona - wszystkie te postacie łączyła nie tylko boska wiedza, ale i świętość. Por. F. Ebeling, The secret history of Hermes Trismegistus. Hermeticism form ancient to modern times, New York 2007, s. 61-62. Idea przekazu odwiecznej prawdy (philosohia perennis) stała się bardzo popularna dzięki założonej przez Ficina Akademii Platońskiej i znalazła swój wyraz m.in. w dziełach Mikołaja z Kuzy (De pace fidei) i Aggostino Steuco (De perenni philosophia).

${ }_{23}$ Przykładowo, jeśli państwo opiekuńcze i emancypacja kobiet rzeczywiście są zgodne z Bożym zamysłem objawionym przez Chrystusa, to ruchy społeczne zmierzające do osiągnięcia tych celów zyskują specyficzny religijny charakter. 
„reguł przekładu” można wyróżnić trwałą treść i zmienne postacie, w jakich jest wyrażana.

3. Próby budowania teologii opartej na poszukiwaniu „prawdziwego” sensu chrześcijaństwa (niezależnego od dziejowych form) jawią się jako nie tylko złudne, ale wręcz niebezpieczne - pod pozorem odkrywania autentycznego sensu Objawienia ukrytego w zmiennych formach prowadzą do stopniowej desakralizacji Tradycji, pojętej w takim przypadku jako drugorzędny i względny „nośnik” zbawczych prawd.

4. Mając na uwadze powyższe wnioski, warto zadać sobie pytanie, czy aby na pewno nawoływania wspomnianych w przytoczonym cytacie „gorliwców, odzianych w jakiś autorytet” są zupełnie bezpodstawne. Być może ich głos jest wyrazem głębokiej intuicji, sięgającej samej istoty naszego bytowania jako animal symbolicum, o nieodzowności symbolicznego pojmowania tego, co ostateczne, i zasadniczej roli „formy” w przekazie zbawczego orędzia Ewangelii ${ }^{24}$.

\section{ABSTRAKT}

\section{Uwagi na temat możliwości rozróżnia między „formą” a „sensem” ekspresji religijnej}

Przedmiotem artykułu jest przedstawienie problematyki związanej z leżącym u podstaw „modernizacji” języka teologii rozróżnieniem na absolutny/ahistoryczny „sens” Objawienia oraz jego relatywną/dziejowo uwarunkowaną „formę”. Celem analiz jest wykazanie, że owo rozróżeninie nie może być pojmowane jako obowiązujące absolutnie. Jest ono jedynie relatywnie ważne, gdy występuje w ramach poszczególnych teologicznych „paradygmatów”. Dodatkowo wskazano argumenty za tezą, wedle której takie próby „modernizacji” form wyrazu mogą przyczyniać się do stopniowej laicyzacji chrześcijańskiego przesłania.

${ }^{24}$ Myśl, którą w tym miejscu można jedynie zasugerować, dobrze oddaje P. Tillich, stwierdzając, że nowoczesny człowiek nie tylko pozbawił się, właściwego religii, „wymiaru głębi”, ale także „okradł się z symboli tego wymiaru, stał się częścią tej horyzontalnej płaszczyzny. Utracił swą identyczność i sam stał się rzeczą pośród rzeczy, stał się składnikiem obliczalnego procesu produkcji i wyliczalnego spożycia”. P. Tillich, Utracony wymiar, przeł. J. Kłoczowski, „W drodze” 1973, nr 2, s. 6. Tillich nie tylko celnie diagnozuje współczesną kulturę, ale również wskazuje remedium. W obliczu zatraty symboli wyrażających istotę religii, „[m]iast udzielać przedwczesnych i zwodniczych odpowiedzi, religie muszą pomóc człowiekowi w zrozumieniu na nowo starych symboli i ich znaczenia dla naszej obecnej sytuacji. Wtedy ich odrodzenie może się stać twórczą mocą w naszej kulturze i zbawczą siłą dla człowieka, który żyje wyobcowany, zalękły, pełen wątpliwości”. Tamże, s. 8. 


\section{SŁOWA KLUCzowe}

religia, język, desakralizacja, forma, istota

\section{Abstract}

\section{Some remarks concerning distinction between "form" and "significancy" of religious expressions}

The purpouse of this paper is to examine basal assumptions lying at the bottom of intentional transformations of religious expression's forms. According to examined concept "forms" in which these ideas are transmited and taught, are historicaly conditioned, variable and thus should be adjusted to mentality of conteporary culture. This proposal rest upon assumtion that we are able to distinguish between relative "form" of expresion and its objective "essence"/"menaning". Consideration conducted in an article prove that this assumtion lack of justification and such efforts to "modernise" religious language leads do desacralisation.

\section{KEY WORDS}

religion, language, desacralisation, form, essence

\section{BIBLIOGRAFIA}

Chisholm R. S., Teoria poznania, przeł. R. Ziemińska, Lublin 1994.

Coomaraswamy R. P., The destruction of Christian tradition, Bloomington 2006. Ebeling F., The secret history of Hermes Trismegistus. Hermeticism form ancient to modern times, New York 2007.

Feyerabend P. K., Jak być dobrym empirysta, przeł. K. Zamiara, Warszawa 1979. Ficino M., Platonic theology, vol. 1, trad. M. J. B. Allen, J. Hankins, London 2001-2006. Gilson E., Jedność doświadczenia filozoficznego, przeł. Z. Wrzeszcz, Warszawa 1968. Justyn Męczennik, Apologia, [w:] M. Michalski, Antologia literatury patrystycznej, t. 1, Warszawa 1975.

Krąpiec M. A., Język i świat realny, Lublin 1985.

Kuhn T., Struktura rewolucji naukowych, przeł. H. Ostromęcka, Warszawa 2009. Pietras H., Eschatologia Kościoła pierwszych czterech wieków, Kraków 2007. Quine W. V., Z punktu widzenia logiki, przeł. B. Stanosz, Warszawa 2004. Tacjan Syryjczyk, Przemowa do Greków, [w:] M. Michalski, Antologia literatury patrystycznej, t. 1, Warszawa 1975.

Tillich P., Utracony wymiar, przeł. J. Kłoczowski, „W Drodze” 1973, nr 2, s. 3-9. 